\title{
Profil disiplin belajar serta implikasinya terhadap layanan bimbingan dan konseling siswa sekolah menengah atas
}

\author{
Desy Wulandari ${ }^{1}$ ), Solihatun Solihatun $\left.{ }^{2 *}\right)$, Maria Oktasari ${ }^{3}$ ) \\ 1,2,3) Universitas Indraprasta PGRI \\ *) solihatunsolie@gmail.com
}

Article History: Received: $12 / 04 / 2021$ Revised: 30/05/2021; Accepted: 04/06/2021 Published: 28/062021.

How to cite: Wulandari, D., Solihatun, S., \& Oktasari, M. (2021). Profil disiplin belajar serta implikasinya terhadap layanan bimbingan dan konseling siswa sekolah menengah atas. Orien: Cakrawala Ilmiah Mahasiswa, 1(1), pp. 31-40. DOI:

10.30998/ocim.v1i1.4570

\footnotetext{
(c) (i) This is an open access article distributed under the Creative Commons 4.0 Attribution License, which permits unrestricted use, distribution, and reproduction in any medium, provided the original work is properly cited. ( 2021 , Wulandari, D., Solihatun, S., \& Oktasari, M.
}

\begin{abstract}
Abstrak: Penelitian ini bertujuan untuk mengetahui profil disiplin belajar serta implikasinya terhadap layanan bimbingan dan konseling. Penelitian ini merupakan penelitian kuantitatif dengan jenis deskriptif. Sampel dalam penelitian ini sebesar 70 siswa ditarik dengan teknik random sampling. Data dikumpulkan dengan menggunakan teknik angket. Data dikumpulkan melalui skala disiplin belajar siswa. Data diolah dengan menggunakan statistika deskriptif. Hasil penelitian ini adalah a) kategori sangat tinggi sebanyak 14 siswa dengan persentase $20 \%$, b) kategori tinggi sebanyak 43 siswa dengan persentase $61.4 \%$., dan c) kategori sedang sebanyak 13 siswa dengan persentase $18,5 \%$
\end{abstract}

Kata Kunci: disiplin belajar, layanan bimbingan dan konseling

Abstract: This study aims to determine the profile of learning disciplines and their implications for guidance and counseling services. This research is a quantitative research with descriptive type. The sample in this study was 70 students drawn by random sampling technique. Data were collected using a questionnaire technique. Data were collected through a student learning discipline scale. The data was processed using descriptive statistics. The results of this study are a) very high category as many as 14 students with a percentage of $20 \%$, b) high category as many as 43 students with a percentage of $61.4 \%$., and c) medium category as many as 13 students with a percentage of $18.5 \%$.

Keywords: learning discipline, guidance and counseling services

\section{Pendahuluan}

Pendidikan merupakan faktor utama dalam pembentukan pribadi manusia (Farida, 2015). Pendidikan sangat berperan dalam membentuk baik atau buruknya pribadi manusia menurut ukuran normatif. Selanjutnya, menurut (Prayitno, 2004) menjelaskan bahwa tujuan pendidikan pada dasarnya adalah arah yang hendak dicapai demi terwujudnya tujuan hidup manusia, yaitu hidup sesuai Harkat dan Martabat Manusia dengan segenap kandungannya, dimensi kemanusiaan dan pancadaya.

Dalam pendidikan individu dapat mengembangkan, menguasai pengetahuan, pemahaman, dan sikap (Ramdhani, 2017). Dalam proses pendidikan siswa mampu menyesuaikan diri dengan lingkungan dan menimbulkan perubahan pada dirinya sehingga berfungsi dalam kehidupan lingkungan dan masyarakat. Pendidikan juga merupakan sarana dalam menjadikan individu yang berkualitas, cerdas dan bermoral. Melalui pendidikan setiap 
individu dapat mengembangkan potensi dan keterampilan yang bermanfaat bagi kehidupannya. Sehingga pendidikan bertujuan untuk menjadikan manusia yang utuh dan sempurna.

Dalam rumusan Undang-undang Republik Indonesia tentang Sistem Pendidikan Nasional Nomor 20 Tahun 2003 yang menjelaskan: Pendidikan adalah usaha sadar dan terencana untuk mewujudkan suasana belajar dan proses pembelajaran agar peserta didik secara aktif mengembangkan potensi dirinya untuk memiliki kekuatan spiritual keagamaan, pengendalian diri, kepribadian, kecerdasan, akhlak mulia, serta keterampilan yang diperlukan dirinya, masyarakat, berbangsa dan bernegara (Indonesia, 2003).

Sekolah tempat anak menjadi manusia yang memiliki pengetahuan, keterampilan, kemampuan dan tujuan masa depannya. Dalam peraturan siswa harus mengikuti dan mentaati peraturan, nilai, dan hukum yang berlaku. Menurut Salah satu faktor yang mempengaruhi disiplin belajar untuk mendorong siswa mendapatkan motivasi siswa belajar dengan sebaikbaiknya sesuai dengan metode belajar di sekolah dan dapat membagi waktu belajar dengan baik Siswa mengikuti seluruh mata pelajaran dan membuat tugas yang diberikan oleh guru dan termotivasi untuk bersaing dalam mencapai prestasi belajar yang tinggi.

Disiplin belajar sangat penting, karena sikap disiplin bertujuan untuk menjaga perilaku yang menyimpang dan hal-hal yang dapat menganggu dalam proses pembelajaran. Dengan disiplin membuat siswa terlatih dan mempunyai kebiasaan melakukan tindakan yang baik serta dapat mengontrol setiap tindakannya sehingga siswa akan taat, patuh dan tertib terhadap kegiatan belajar mengajar (Amalia, Dimyati, \& Marjo, 2016). Di dalam pembelajaran, disiplin sangat dibutuhkan karena tanpa adanya kesadaran melaksanakan aturan yang ditetapkan sebelumnya, pembelajaran tidak akan berjalan efektif dan optimal. Oleh karena itu, agar pembelajaran berjalan lancar maka semua siswa harus disiplin baik disiplin mentaati peraturan sekolah, disiplin mengerjakan pekerjaan rumah (PR), disiplin dalam mengerjakan tugas, dan disiplin dalam belajar di rumah (Dianto, 2017).

Tingkat kedisiplinan belajar setiap siswa akan berbeda-beda. Siswa yang terbiasa dalam disiplin belajar akan mempergunakan waktu sebaik-baiknya di rumah maupun di sekolah sehingga akan menunjukkan kesiapannya dalam proses pembelajaran di sekolah, sedangkan siswa yang tidak disiplin belajar mereka kurang menunjukkan kesiapannya dalam belajar sehingga mengalami kesulitan dalam belajar (Solihatun, 2019b).

Sejalan dengan pernyataan oleh (Dimyati, 2006) perilaku disiplin tidak akan tumbuh dengan sendirinya, melainkan perlu kesadaran diri, latihan, kebiasaan, dan juga adanya hukuman. Bagi siswa disiplin belajar juga tidak akan tercipta apabila siswa tidak mempunyai kesadaran diri. Siswa akan disiplin dalam belajar apabila siswa sadar akan pentingnya belajar dalam kehidupannya. Siswa yang sudah terbiasa disiplin, sikap dan perbuatan disiplin yang dilakukan bukan lagi dirasakan sebagai suatu beban, melainkan suatu tindakan yang sudah biasa dilakukan setiap hari. Siswa yang sadar akan pentingnya belajar akan menunjukkan perilaku yang memiliki kecenderungan disiplin yang tinggi dalam dirinya, di samping itu juga akan timbul suatu prinsip dalam diri siswa. Mereka menyadari bahwa dengan disiplin belajar akan mempermudah kelancaran di dalam proses pendidikan. Hal ini terjadi karena dengan disiplin rasa segan, rasa malas, dan rasa membolos akan teratasi (Ilyas, Folastri, \& Solihatun, 2017).

Di dalam proses belajar mengajar, disiplin terhadap peraturan dan tata tertib yang wajib diterapkan, karena peraturan dan tata tertib merupakan suatu kesatuan yang tidak dapat dipisahkan sebagai pembentukan disiplin siswa dalam mentaati peraturan di dalam kelas maupun di luar kelas. Tanpa disiplin yang baik, suasana sekolah dan juga kelas menjadi kurang kondusif bagi kegiatan pembelajaran sehingga proses belajar mengajar tidak akan berjalan 
dengan lancar sesuai dengan rencana, sehingga menyebabkab siswa mengalami kesulitan belajar (Solihatun \& Folastri, 2019).

Jadi, proses belajar yang baik adalah belajar yang bisa memudahkan siswa dalam memahami materi pelajaran yang diajarkan (Solihatun, 2019a). Dalam proses belajar mengajar akan timbul suatu tanggapan dari siswa, tanggapan ini akan mempengaruhi perilaku siswa selanjutnya. Dengan kata lain tingkah laku siswa dalam belajar ditentukan oleh bagaimana tanggapannya tentang objek atau sesuatu yang diamati.

Fungsi disiplin sangat penting dan dibutuhkan oleh setiap siswa, karena disiplin menjadi prasyarat bagi pembentukan sikap, perilaku dan tata kehidupan, disiplin yang akan mengantar seorang siswa sukses dalam belajar dan kelak ketika bekerja (Tu'u, 2004). Sikap disiplin yang dibawa dari lingkungan keluarga merupakan modal besar bagi pembentukan sikap kedisiplinan di lingkungan sekolah. Pembiasaan disiplin di sekolah akan mempunyai pengaruh positif bagi kehidupan siswa di masa yang akan datang.

Berdasarkan Penelitian yang dilakukan oleh (Sonjaya, 2017) Profil Disiplin Belajar Siswa dan Implikasinya Bagi Layanan Bimbingan dan Konseling (Studi Deskriptif terhadap Siswa Kelas VIII SMP Negeri 40 Bandung Tahun Ajaran 2016/2017) untuk mewujudkan proses belajar yang baik dan teratur, siswa harus memiliki kemampuan dalam mengatur waktu belajar yang terencana agar tercapai suatu hasil belajar yang optimal, oleh karena itu disiplin belajar sangat diperlukan. Disiplin belajar adalah suatu pengendalian pada diri siswa terhadap aturan tertulis atau tidak tertulis yang telah diterapkan oleh siswa melalui kesadaran akan tugas dan tanggungjawab sebagai pelajar. Tujuan penelitian untuk mengetahui gambaran secara umum disiplin belajar siswa. Desain penelitian yang digunakan yaitu penelitian survei dengan metode survei deskriptif melalui pendekatan kuantitatif. Populasi penelitian berjumlah 366 siswa dan menggunakan sampel sebanyak 200 siswa dengan teknik probability sampling. Data diperoleh dari hasil penyebaran instrumen berupa angket disiplin belajar siswa. Hasil penelitian menunjukan gambaran disiplin belajar siswa secara keseluruhan rata-rata berada pada kategori tinggi artinya siswa dapat mengatur dan bertanggungjawab pada waktu belajarnya. Dalam hal ini, artinya siswa memerlukan layanan bimbingan dan konseling untuk meningkatkan dan memelihara disiplin belajar agar tidak terjadi penurunan perilaku disiplin belajar.

Guru bimbingan dan konseling bertanggung jawab untuk membantu menggembangkan kehidupan pribadi, sosial, kemampuan belajar, dan membantu menggembangkan bakat minatnya agar mengetahui karir yang akan dipilih sehingga pelayanan bimbingan konseling terhadap siswa menjadi tanggungjawabnya. Artinya, membantu siswa agar dapat melaksanakan kehidupannya secara wajar tanpa mengalami masalah sehingga tercapainya kehidupan efektif sehari-hari dan siswa mampu menyelesaikan masalah yang dihadapinya dan mampu mengembangkan potensi yang dimilikinya. Maka bimbingan dan konseling mempunyai peran penting dalam upaya meningkatkan dan memlihara disiplin belajar. Melalui bimbingan belajar disekolah dapat mengarahkan siswa dalam mencapai tujuan belajarnya, sehingga siswa dapat meningkatkan disiplin belajar.

Dengan adanya layanan bimbingan konseling diharapkan siswa mendapatkan bekal dengan berbagai pengetahuan dan pemahaman tentang berbagai hal yang berguna untuk mengenal diri, merencanakan dan mengembangkan kehidupan sebagai pelajar, anggota keluarga dan masyarakat.

Dari gambaran di atas layanan bimbingan dan konseling dapat membantu individu terutama siswa dalam memenuhi kebutuhan akan pengetahuan dan informasi yang dibutuhkannya dalam mengatasi permasalahan yang dialaminya, baik masalah pribadi, lingkungan dan masa depan. 
Selanjutnya, hasil wawancara dengan guru bimbingan dan konseling di Sekolah Menengah Atas Negeri (SMAN) 30 Jakarta Pusat terdapat siswa yang kurang disiplin belajar seperti siswa terlambat pada jam datang masuk sekolah, kurangnya disiplin dalam mengatur waktu, kurang semangat dalam mengikuti pelajaran sehingga penulis akan melakukan penelitian di SMAN 30 Jakarta Pusat.

Berdasarkan permasalahan yang dikemukakan di atas, penelitian ini ingin mengungkapkan profil disiplin belajar siswa selanjutnya, penelitian ini juga bertujuan untuk mengetahui Implikasinya Terhadap Layanan Bimbingan dan Konseling di SMAN 30 Jakarta Pusat. Adapun manfaat dari penelitian ini diharapkan akan menjadi bertambahnya WPKNS (Wawasan, Pengetahuan, Keterampilan, Nilai dan Sikap bagi guru Bimbingan danj Konseling pada khususnya dan bagi guru Mata pelajaran sebagai referensi dalam mengarahkan siswa untuk memiliki disiplin belajar.

\section{Metode}

Metode penelitian yang digunakan dalam penelitian ini adalah metode survei dengan pendekatan deskriptif kuantitatif. Penelitian ini dilaksanakan mulai bulan Juni sampai dengan bulan Juli 2020 di SMAN 30 Jakarta Jalan Ahmad Yani No.43A, RT 016 RW 002, Cempaka Putih Timur Kecamatan Cempaka Putih, Kota Jakarta Pusat, Daerah Khusus Ibukota Jakarta, kode pos 10510.

Populasi dalam penelitian ini adalah siswa kelas X SMAN 30 Jakarta Pusat sejumlah 849. Dalam penelitian ini peneliti menggunakan teknik random sampling sederhana yaitu teknik pengambilan sampling dimana setiap sampel secara acak (Supardi, 2013). Pengertian acak menurut (Ismail, 2018) memiliki dua karakteristik yaitu: (1) Sama atau serata diartikan bahwa setiap individu didalam populasi memiliki kesempatan yang sama untuk dijadikan sampel. (2) Independen diartikan bahwa pemilihan satu individu untuk sampel tidak memiliki kaitan pada pemilihan individu lainnya.Peneliti akan melakukan penelitian kelas X IPS dengan sampel 70 siswa di SMAN 30 Jakarta Pusat sesuai dengan data yang dibutuhkan. Jadi, sampel adalah bagian dari populasi yang dipilih melalui teknik sampling untuk mewakili populasi.

Dalam penelitian ini metode pengumpulan data atau alat pengumpulan data yang digunakan adalah kuesioner (angket), yaitu angket disiplin belajar siswa dengan menggunakan skala Likert. Penggunaan pendekatan untuk mengetahui validitas instrumen dengan ketentuan rhitung $<$ rtabel dengan taraf signifikasi 5\%, sedangkan untuk realibilitasnya dengan menggunakan SPSS 22.

Untuk mendeskripsi profil disiplin belaja siswa yaitu melalui perhitungan rata-rata (Mean) dan Persentase (\%) Disiplin belajar berdasarkan indikator $(\mathrm{n}=70)$.

\section{Hasil dan Diskusi}

Berdasarkan hasil pengolahan data secara keseluruhan jumlah item pernyataan variable disiplin belajar sebanyak 50 butir item, rentang skor dari 1-5, skor tertinggi adalah 225, dan skor terendah 154. Deskrpsi data menggunakan rumus interval yang telah dijelaskan. Analisis deskriptif disiplin belajar siswa dapat dilihat di tabel 1 sebagai berikut: 
Tabel 1. Profil Disiplin Belajar Siswa di SMAN 30 Jakarta Pusat (n=70)

\begin{tabular}{cccc}
\hline Interval Skor & Kategori & Frekuensi & P (\%) \\
\hline $201-250$ & Sangat Tinggi & 14 & 20 \\
$171-200$ & Tinggi & 43 & 61,4 \\
$131-170$ & Sedang & 13 & 18,5 \\
$91-130$ & Rendah & 0 & 0 \\
$50-90$ & Sangat Rendah & 0 & 0 \\
\hline Total & & 70 & 100 \\
\hline
\end{tabular}

Sumber: Diolah dari data penelitian, 2021

Dari tabel 1 di atas, dapat dijelaskan bahwa terdapat siswa yang memiliki disiplin belajar dengan kategori sangat tinggi sebanyak 14 siswa dengan persentase $20 \%$, kategori tinggi sebanyak 43 siswa dengan persentase $61.4 \%$., dan kategori sedang sebanyak 13 siswa dengan persentase 18,5\%. Untuk lebih rinci, dapat dilihat pada tabel 2.

Tabel 2. Deskripsi Rata-Rata dan Persentase Disiplin belajar Berdasarkan Indikator $(\mathbf{n}=\mathbf{7 0})$

\begin{tabular}{|c|c|c|c|c|c|c|c|c|c|}
\hline \multirow{2}{*}{$\begin{array}{c}\text { Sub } \\
\text { Variabel }\end{array}$} & \multirow{2}{*}{ Indikator } & \multicolumn{8}{|c|}{ Skor } \\
\hline & & Ideal & Max & Min & $\Sigma$ & Mean & $\%$ & sd & Ket \\
\hline \multirow{4}{*}{$\begin{array}{l}\text { Disiplin } \\
\text { waktu }\end{array}$} & $\begin{array}{l}\text { Tepat waktu dalam } \\
\text { belajar mencakup jam } \\
\text { datang dan pulang } \\
\text { sekolah tepat waktu, } \\
\text { mulai dari selesai belajar } \\
\text { di rumah dan di sekolah } \\
\text { (8) }\end{array}$ & 40 & 33 & 32 & 2039 & 29 & 72,5 & 2,15 & B \\
\hline & Tidak meninggalkan & & & & & & & & \\
\hline & $\begin{array}{l}\text { kelas/membolos saat } \\
\text { pelajaran (8) }\end{array}$ & 40 & 36 & 26 & 2206 & 32 & 80 & 2.49 & SB \\
\hline & $\begin{array}{ll}\text { Menyelesaikan tugas } \\
\text { sesuai waktu yang } \\
\text { ditetapkan (3) }\end{array}$ & 15 & 15 & 7 & 794 & 11 & 73 & 1,69 & $\mathrm{~B}$ \\
\hline \multirow{6}{*}{$\begin{array}{l}\text { Disiplin } \\
\text { perbuatan }\end{array}$} & $\begin{array}{l}\text { Patuh dan tidak } \\
\text { menentang peraturan } \\
\text { yang berlaku (4) }\end{array}$ & 20 & 19 & 10 & 1037 & 15 & 75 & 2,1 & $\mathrm{~B}$ \\
\hline & Tidak malas belajar (11) & 55 & 18 & 7 & 822 & 12 & 22 & 1,90 & СВ \\
\hline & $\begin{array}{l}\text { Tidak menyuruh orang } \\
\text { lain bekerja demi dirinya } \\
\text { (3) }\end{array}$ & 15 & 15 & 7 & 817 & 12 & 80 & 1,70 & SB \\
\hline & $\begin{array}{l}\text { Tidak suka berbohong } \\
\text { (3) }\end{array}$ & 15 & 15 & 8 & 842 & 12 & 80 & 1,89 & SB \\
\hline & $\begin{array}{l}\text { Tingkah laku } \\
\text { menyenangkan, } \\
\text { mencakup mencontek, } \\
\text { tidak menggangu orang } \\
\text { lain yang sedang belajar } \\
\text { (10) }\end{array}$ & 50 & 20 & 11 & 1101 & 16 & 32 & 1,78 & CВ \\
\hline & Keseluruhan (50) & 250 & 171 & 108 & 9658 & 139 & 56 & 16 & B \\
\hline
\end{tabular}

Sumber: Diolah dari data penelitian, 2021 
Keterangan:

$\begin{array}{ll}\text { Max } & \text { : skor maksimal } \\ \text { Min } & \text { : skor minimal } \\ \text { Sd } & \text { : standar deviasi } \\ \text { B } & \text { : baik }\end{array}$

SB : sangat baik

Berdasarkan Tabel 2, terlihat bahwa secara rata-rata keseluruhan disiplin belajar siswa berada pada kategori baik, dengan tingkat capaian sebesar $56 \%$. Hal ini juga terlihat dari analisis masing-masing indikator yang berada pada kategori baik. Namun, pada indikator kesediaan resiko berada pada kategori sangat baik yaitu $80 \%$. Selanjutnya, akan dijelaskan deskripsi ratarata (mean) dan Persentase (\%). Untuk melihat secara rinci gambaran disiplin belajar berdasarkan indicator siswa kelas $\mathrm{X}$ dapat dilihat pada tabel 3.

Tabel 3. Gambaran Disiplin Belajar Berdasarkan Indikator Siswa Kelas X SMA Negeri 30 Jakarta Pusat

\begin{tabular}{clc}
\hline Variabel & \multicolumn{1}{c}{ Indikator } & \multicolumn{1}{c}{ Persentase (\%) } \\
\hline & $\begin{array}{l}\text { Tepat waktu dalam belajar mencakup jam datang dan pulang } \\
\text { sekolah tepat waktu, mulai dari selesai belajar di rumah dan }\end{array}$ & 72,5 \\
Disiplin & $\begin{array}{l}\text { di sekolah } \\
\text { Waktu }\end{array}$ & Tidak meninggalkan kelas/membolos saat pelajaran \\
& Menyelesaikan tugas sesuai waktu yang ditetapkan & 80 \\
\hline \multirow{2}{*}{ Disiplin } & Patuh dan tidak menentang peraturan yang berlaku & 73 \\
\hline perbuatan & Tidak malas belajar & 75 \\
& Tidak menyuruh orang lain bekerja demi dirinya & 22 \\
& Tingkah laku menyenangkan, mencakup mencontek, tidak & 80 \\
& menggangu orang lain yang sedang belajar & 80 \\
\hline
\end{tabular}

Sumber: Diolah dari data penelitian, 2021

Berdasarkan Tabel 3 di atas, dapat dilihat bahwa persentase (\%) disiplin belajar siswa terdapat dua variabel adalah disiplin waktu dan disiplin perbuatan. Ada empat indikator yang harus ditingkatkan yaitu tidak meninggalkan kelas/membolos saat pelajaran $80 \%$, menyelesaikan tugas sesuai waktu yang ditetapkan $73 \%$, patuh dan tidak menentang peraturan yang berlaku $75 \%$, tidak malas belajar $22 \%$.

Berdasarkan hasil uji validitas dengan ketentuan rhitung $<$ rtabel dengan taraf signifikasi 5\% maka didapatkan hasil dari 50 item yang dinyatakan ada 49 item dan 1 item tidak valid dengan 1 item nomor 36 (Saya membawa semua buku pembelajaran setiap hari).

Sedangkan uji reliabilitas menurut (Sugiyono, 2009) dilakukan untuk mengetahui seberapa jauh hasil pengukuran tetap konsisten apabila dilakukan pengukuran dua kali atau lebih terhadap gejala yang sama dengan menggunakan alat pengukur sama. Hasil hitungan reliabilitas melalui angket dengan menggunakan SPSS 22 adalah 0,882. Nilai tersebut menunjukan bahwa angket disiplin belajar reliabel, sehingga dapat diandalkan untuk digunakan sebagai instrument angket penelitian. Berdasarkan hasil pengujian reliabilitas maka semua item 
dalam angket disiplin belajar terlihat nilai alpha adalah sebesar 0,882. Dengan hasil alpha maka kesimpulan yang dapat diambil adalah reliabel.

Teknik yang digunakan untuk menguji normalitas data yaitu menggunakan SPSS 22.0 dengan menggunakan Kolmogorov-Smirnov. Untuk menguji normalitas data dapat menggunakan Kolmogorov-Smirnov dengan kententuan :

1. Jika hasil signifikasi Kolmogorov-Smirnov menunjukkan nilai $>0,05$ maka data residual terdistribusi dengan normal.

2. Jika hasil signifikasi Kolmogorov-Smirnov menunjukkan nilai signifikasi $<0,05$ maka data residual tidak terdistribusi dengan normal.

Berdasarkan hasil uji normalitas diketahui bahwa nilai signifikan disiplin belajar adalah 0,200 yang menunjukkan nilai disiplin belajar > 0,05. Jadi, data disiplin belajar berdistribusi normal. Selanjutnya, hasil penelitian yang dilakukan bahwa siswa di SMA Negeri 30 Jakarta Pusat sebanyak 70 responden memiliki tingkat disiplin belajar yang baik. Dengan menggunakan layanan bimbingan dan konseling adalah layanan orientasi, layanan informasi, layanan konseling individual/perorangan, layanan bimbingan kelompok dan layanan konseling kelompok.

1. Deskripsi disiplin belajar siswa SMA Negeri 30 Jakarta Pusat

Dalam penelitian disiplin belajar siswa kelas X SMA Negeri 30 Jakarta Pusat dapat mengatur tingkah laku, memiliki disiplin belajar yang dapat mengikuti dan menaanti peraturan, nilai dan perilaku yang baik. Kemampuan siswa untuk memperoleh pengetahuan, pemahaman, etika, dan tingkah laku dalam pengalaman yang menyangkut kognitif, afektif dan psikomotor siswa.

Berdasarkan hasil penelitian, disiplin belajar yang dimiliki kelas X di SMA Negeri 30 Jakarta Pusat berada dikategori tinggi 43 siswa $(61,4 \%)$ dengan kemampuan dalam mengembangkan dan mengendalikan tingkah laku di sekolah, rumah dan lingkungan masyarakat dalam menaati peraturan dan tata tertib yang timbul berdasarkan dorongan dan kesadaran tanpa adanya paksaan.

Gambaran hasil penelitian menunjukan siswa kelas X SMA Negeri 30 Jakarta Pusat memiliki disiplin yang tinggi. Sejalan dengan hasil penelitian oleh (Widayati, 2020) menyatakan bahwa disiplin belajar adalah suatu posisi kecenderungan, suatu sikap mental untuk mematuhi aturan, tata tertib dan sekaligus mengendalikan dan menyesuaikan diri terhadap aturan-aturan yang berasal dari luar sekalipun yang mengekang dan menunjukkan kesadaran akan tanggung jawab terhadap tugas dan kewajiban.

2. Implikasi layanan bimbingan dan konseling

Dari hasil penelitian dilapangan dalam disiplin belajar siswa kelas X di SMA Negeri 30 Jakarta Pusat terdapat tiga indikator yang ditemukan yaitu terdapat siswa yang kurang disiplin belajar seperti siswa terlambat pada jam datang masuk sekolah, kurangnya disiplin dalam mengatur waktu, kurang semangat dalam mengikuti pelajaran belajar sehingga sebagai rujukan bagi guru Bimbingan dan Konseling dalam pemberian layanan bimbingan dan konseling yang bisa diberikan pada siswa agar hasil dari proses pembelajaran dalam pemberian layanan adalah layanan orientasi dengan materi pengenalan tata tertib sekolah (Sutrisno, 2019), layanan informasi dengan mengkombinasikan Metode Ceramah, Sosiodrama, dan Diskusi (Sudirman, Mudjiran, \& Rusdinal, 2015), layanan konseling perorangan dengan menggunakan teknik Eklektik dalam upaya peningakatan kehadiran siswa (Mulyani, 2017), layanan bimbingan kelompok (Dewi, 2014), dan penggunaan strategi pengelolaan diri dalam layanan konseling kelompok (Luki Hayati \& Darminto, 2019). Lebih lanjut menurut Sukardi \& Kusmawati (Maufiroh \& Endang, 2015) melalui layanan Bimbingan dan konseling untuk membantu siswa 
mengembangkan diri, sikap, dan kebiasaan belajar yang baik, untuk menguasai pengetahuan dan keterampilan serta menyiapkannya melanjutkan pendidikan pada tingkat yang lebih tinggi. Selanjutnya, tujuan adanya perencanaan pemberian layanan bimbingan dan konseling adalah agar pelaksanaan program bimbingan dapat mengontrol dan mengevaluasi kegiatan bimbingan yang dilakukan dan terlaksanaya program kegiatan secara lancar, efesian dan efektif. (Winkel, 2006)

\section{Simpulan}

Profil disiplin belajar siswa kelas X di SMA Negeri 30 Jakarta Selatan dengan hasil penelitian pada kategori tinggi 43 siswa $(61,4 \%)$ berarti disiplin belajar siswa di SMA Negeri 30 Jakarta Pusat tinggi artinya siswa sudah dapat mengatur, mengelola waktu, kemampuan dalam mengembangkan belajar sehingga siswa mampu bertanggungjawab dan mengendalikan tingkah laku di sekolah, rumah dan lingkungan masyarakat dalam menaati peraturan dan tata tertib yang timbul berdasarkan dorongan dan kesadaran tanpa adanya paksaan. Sedangkan siswa pada kategori sedang 13 siswa (18,5\%) berarti disiplin belajar siswa di SMA Negeri 30 Jakarta Pusat dalam mengendalikan perilaku dan menaati peraturan dan tata tertib di sekolah, di rumah dan dilingkungan masyarakat namun sulit untuk melakukannya.

Implikasinya layanan Bimbingan dan Konseling di SMAN 30 Jakarta Pusat dengan hasil angket dengan guru bimbingan dan konseling di SMA Negeri 30 Jakarta Pusat memberikan layanan klasikal dengan implikasi yang diberikan pada siswa kelas $\mathrm{X}$ dalam disiplin belajar adalah layanan orientasi, layanan informasi, layanan konseling perorangan, layanan bimbingan kelompok dan layanan bimbingan konseling kelas X di SMA Negeri 30 Jakarta Pusat disiplin belajar akan dikembangkan berdasarkan hasil penelitian tingkatan disiplin belajar siswa yang telah diperoleh, khususnya pada setiap masing-masing indikator yang terdapat disiplin belajar. Layanan Bimbingan dan Konseling diberikan bertujuan untuk meningkatkan dan memelihara disiplin belajar siswa ketingkat kategori yang lebih tinggi dan mempertahankan kategori yang sudah tinggi agar siswa dapat memepertahankan perilaku yang sudah baik tersebut.

\section{Ucapan Terima Kasih}

Terima kasih teramat dalam kepada Kepala Sekolah SMA Negeri 30 Jakarta Pusat Ibu Agnes Sukasni, M. Pd., Kepada Guru Bimbingan dan Konseling SMA Negeri 30 Jakarta Pusat Ibu Junistari, S. Pd. sehingga sukses nya penelitian ini.

\section{Daftar Rujukan}

Amalia, D., Dimyati, M., \& Marjo, H. K. (2016). Profil Komitmen Belajar Siswa Kelas VIII Di Sekolah Menengah Pertama Taruna Bhakti Depok. INSIGHT: Jurnal Bimbingan Konseling, 5(1), 43-50. https://doi.org/https://doi.org/10.21009/INSIGHT.051.07

Dewi, N. (2014). Efektifitas Layanan Bimbingan Kelompok dalam Meningkatkan Disiplin Belajar Siswa SMP Negeri 2 Kalianget Tahun Pelajaran2013-2014. Retrieved from https://repository.stkippgrisumenep.ac.id/70/

Dianto, M. (2017). Profil Dukungan Sosial Orangtua Siswa di SMP Negeri Kecamatan Batang Kapas Pesisir Selatan. Jurnal Counseling Care, 1(1), 42-51. Retrieved from http://ejournal.stkip-pgri-sumbar.ac.id/index.php/counseling/article/view/1994

Dimyati, M. (2006). Belajar dan pembelajaran. Jakarta: Rineka Cipta. 
Farida, Y. E. (2015). Humanisme Dalam Pendidikan Islam. Tarbawi: Jurnal Pendidikan Islam, 12(1). https://doi.org/https://doi.org/10.34001/tarbawi.v12i1.306

Ilyas, A., Folastri, S., \& Solihatun, S. (2017). Diagnosa Kesulitan Belajar \& Pembelajaran Remidial. Jakarta: Perpustakaan Nasional: Katalog Dalam Terbitan (KTD).

Indonesia, P. R. (2003). Undang-undang Republik Indonesia nomor 20 tahun 2003 tentang sistem pendidikan nasional. Departemen Pendidikan Nasional.

Ismail, H. F. (2018). Statistika untuk penelitian pendidikan dan ilmu-ilmu sosial. Kencana.

Luki Hayati, M., \& Darminto, E. (2019). Keefektifan Penggunaan Strategi Pengelolaan Diri Dalam Konseling Kelompok Untuk Meningkatkan Disiplin Belajar Peserta Didik. Jurnal BK Unesa, $9(2)$.

Maufiroh, D. L., \& Endang, B. (2015). Pengaruh Bimbingan Belajar Terhadap Motivasi Belajar Siswa Kelas X IPA di SMAN 10 Pontianak. Jurnal Pendidikan Dan Pembelajaran Khatulistiwa, 4(7). Retrieved from https://jurnal.untan.ac.id/index.php/jpdpb/article/view/10801/10326

Mulyani, A. (2017). Peningkatan Kehadiran Siswa kelas XI Pemasaran 2 Menggunakan Konseling Perorangan Teknik Eklektik. Jurnal Konseling Dan Pendidikan, 5(3), 167-171. https://doi.org/https://doi.org/10.29210/120000

Prayitno, E. A. (2004). Dasar-dasar Bimbingan dan Konseling (Jakarta). Rineka Cipta.

Ramdhani, M. A. (2017). Lingkungan pendidikan dalam implementasi pendidikan karakter. Jurnal Pendidikan UNIGA, 8(1), 28-37. https://doi.org/http://dx.doi.org/10.52434/jp.v8i1.69

Solihatun, S. (2019a). Gambaran kebiasaan belajar siswa serta Implikasi nya terhadap Pelayanan Bimbingan dan Konseling. Biblio Couns: Jurnal Kajian Konseling Dan Pendidikan, 2(1), 41-46. https://doi.org/http://dx.doi.org/10.30596\%2Fbibliocouns.v2i1.2278

Solihatun, S. (2019b). Gambaran Kesulitan Belajar Siswa Serta Implikasinya Terhadap Pelayanan Bimbingan dan Konseling. Jurnal Counseling Care, 2(2), 56-64. https://doi.org/https://doi.org/10.22202/jcc.2018.v2i2.3061

Solihatun, S., \& Folastri, S. (2019). Program bimbingan dan konseling untuk mengatasi kesulitan belajar siswa SD Negeri 05 Ciganjur Jakarta Selatan. TERAPUTIK: Jurnal Bimbingan Dan Konseling, 3(1), 35-40. https://doi.org/10.30998/teraputik.31122

Sonjaya, O. F. (2017). Profil Disiplin Belajar Siswa dan Implikasinya Bagi Layanan Bimbingan dan Konseling: Studi Deskriptif terhadap Siswa Kelas VIII di SMP Negeri 40 Bandung Tahun Ajaran 2016/2017. Universitas Pendidikan Indonesia.

Sudirman, A., Mudjiran, M., \& Rusdinal, R. (2015). Efektivitas Layanan Informasi yang Mengkombinasikan Metode Ceramah, Sosiodrama, dan Diskusi dalam Merubah Persepsi Siswa Tentang Disiplin Belajar. Konselor, 4(1), 33-41. https://doi.org/https://doi.org/10.24036/02015416453-0-00

Sugiyono, M. P. P., \& Kuantitatif, P. (2009). Kualitatif, dan R\&D, Bandung: Alfabeta. Cet. VII.

Supardi, U. S. (2013). Aplikasi statistika dalam penelitian. Jakarta: Change Publisher.

Sutrisno, T. (2019). Penerapan Layanan Orientasi pada Materi Pengenalan Tata Tertib Sekolah Dalam Upaya Meningkatkan Kedisiplinan Siswa. MUBTADI: Jurnal Pendidikan Ibtidaiyah, 1(1), 14-29. https://doi.org/https://doi.org/10.19105/mubtadi.v1i1.2989 
40 Profil disiplin belajar serta implikasinya terhadap ...

Tu'u, T. (2004). Peran disiplin pada perilaku dan prestasi siswa. Jakarta: Grasindo, 82.

Widayati, K. (2020). Pengaruh Motivasi dan Kedisiplinan Terhadap Prestasi Belajar PPKn Siswa Kelas VIII SMP Muhammadiyah 13 Wonosegoro. WASPADA (Jurnal Wawasan Pengembangan Pendidikan), 4(2), 63-79.

Winkel, H. (2006). Bimbingan dan Konseling di Institusi Pendidikan Yogyakarta: Media Abadi.

\section{Competing interests:}

The authors declare that they have no significant competing financial, professional or personal interests that might have influenced the performance or presentation of the work described in this manuscript. 